\title{
Career commitment and career entrenchment among Primary Health Care workers
}

\author{
Comprometimento e entrincheiramento com a carreira em trabalhadores da Atenção Primária à Saúde \\ Compromiso y afianzamiento con la carrera del personal de la Atención Primaria de Salud
}

\begin{tabular}{r}
\hline Luciano Garcia Lourenção' \\
ORCID: 0000-0002-1240-4702 \\
Jacqueline Flores de Oliveira' \\
ORCID: 0000-0002-0598-3881 \\
Francisco Rosemiro Guimarães Ximenes Neto"' \\
ORCID: 0000-0002-7905-9990 \\
Carlos Leonardo Figueiredo Cunha'"' \\
ORCID: 0000-0002-1891-4201 \\
Sandra Verónica Valenzuela-Suazo'v \\
ORCID: 0000-0002-1308-4835 \\
Márcio Andrade Borges' \\
ORCID: 0000-0002-4597-2597 \\
Cláudia Eli Gazettav \\
ORCID: 0000-0002-2603-8803
\end{tabular}

'Universidade Federal do Rio Grande. Rio Grande, Rio Grande do Sul, Brazil.

"Universidade Estadual Vale do Acaraú. Sobral, Ceará, Brazil.

I' Universidade Federal do Pará. Belém, Pará, Brazil. "v Universidad de Concepción. Concepción, Bío-Bío, Chile.

${ }^{v}$ Faculdade de Medicina de São José do Rio Preto. São José do Rio Preto, São Paulo, Brazil.

How to cite this article: Lourenção LG, Oliveira JF, Ximenes Neto FR, Cunha CLF, Valenzuela-Suazo SV, Borges MA, et al. Career commitment and career entrenchment among Primary Health Care workers. Rev Bras Enferm. 2022;75(1):e20210144. https://doi.org/10.1590/0034-7167-2021-0144

Corresponding author: Luciano Garcia Lourenção E-mail: lucianolourencao.enf@gmail.com

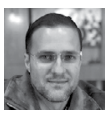

EDITOR IN CHIEF: Antonio José de Almeida Filho ASSOCIATE EDITOR: Alexandre Balsanelli

\begin{abstract}
Objective: Assess levels of career commitment and career entrenchment among Primary Health Care workers. Methods: This Cross-sectional study addressed 393 workers using the Brazilian versions of the Career Commitment Measure (CCM) and Career Entrenchment Measure (CEM). Results: Levels of Career commitment [75.5-77.5] were higher $(p<0.001)$ than Career Entrenchment [66.7-69.2]. Identity levels [82.7-85.5] were higher $(p<0.001)$ than Investment levels [60.4-65.0]. Career resilience levels [75.1-79.2] were higher $(p<0.001)$ than Emotional costs [69.0-72.1]. Planning levels [64.2-67.1] were lower $(p<0.001)$ than levels of limitedness of career alternatives [68.1-71.0]. Conclusion: The highest scores were obtained in Career commitment, showing the workers' identification and positive relationship with their careers, that is, these workers remain in Primary Health Care services because they identify themselves with their professions. Descriptors: Career Mobility; Primary Health Care; Employment; Health Personnel; Occupational Health.
\end{abstract}

\section{RESUMO}

Objetivo: Avaliar os níveis de comprometimento e entrincheiramento com a carreira de trabalhadores da Atenção Primária à Saúde. Métodos: Estudo transversal com 393 trabalhadores, utilizando as versões brasileiras das Escalas de Comprometimento com a Carreira (ECC) e de Entrincheiramento na Carreira (EEC). Resultados: Os níveis de Comprometimento $[75,5-77,5]$ foram superiores $(p<0,001)$ aos de Entrincheiramento $[66,7-69,2]$. Os níveis de Identidade $[82,7-85,5]$ foram superiores $(p<0,001)$ aos níveis de Investimentos $[60,4-65,0]$. Os níveis de Resiliência com a carreira $[75,1-79,2]$ foram superiores $(p<0,001)$ aos níveis de Custos emocionais com a carreira $[69,0-72,1]$. Os níveis de Planejamento $[64,2-67,1]$ foram inferiores $(p<0,001)$ aos níveis de Limitação de alternativas $[68,1-71,0]$. Conclusão: Predominou o vínculo de comprometimento com a carreira, evidenciando identificação e relação positiva dos trabalhadores com a carreira, os quais permanecem na Atenção Primária à Saúde porque se identificam com a profissão. Descritores: Mobilidade Ocupacional; Atenção Primária à Saúde; Emprego; Pessoal de Saúde; Saúde do Trabalhador.

\section{RESUMEN}

Objetivo: Evaluar los niveles de compromiso y afianzamiento con la carrera del personal de la Atención Primaria de Salud. Métodos: Se trata de un estudio transversal, realizado entre 393 trabajadores, en el que se utilizaron las versiones brasileras de las Escalas de Compromiso con la Carrera (ECC) y de Afianzamiento con la Carrera (EEC). Resultados: Los niveles de Compromiso [75,5 - 77,5] eran superiores $(p<0,001)$ a los de Afianzamiento $[66,7-69,2]$. Los niveles de Identidad $[82,7-85,5]$ eran superiores $(p<0,001)$ a los de Inversión $[60,4-65,0]$. Los niveles de Resiliencia con la carrera $[75,1-79,2]$ eran superiores $(p<0,001)$ a los de Costo emocional $[69,0-72,1]$. Los niveles de Planificación $[64,2-67,1]$ eran inferiores $(p<0,001)$ a los de Limitación de alternativas $[68,1-71,0]$. Conclusión: Predominó el vínculo de compromiso con la carrera, lo que demuestra una identificación y relación positiva de los trabajadores con la misma y permanecen en la Atención Primaria de Salud porque se identifican con la profesión. Descriptores: Movilidad Laboral; Atención Primaria de Salud; Empleo; Personal de Salud; Salud Laboral. 
Career commitment and career entrenchment among Primary Health Care workers Lourenção LG, Oliveira JF, Ximenes Neto FR, Cunha CLF, Valenzuela-Suazo SV, Borges MA, et al.

\section{INTRODUCTION}

In Brazil, the large contingent that makes up the workforce of Primary Health Care (PHC) workers experiences intense social and labor vulnerability. The literature reports the precarious working conditions of these workers, with weak or temporary job contracts, low salaries, not job position or salary plans, increased outsourcing, high turnover, and illnesses. All these factors compromise the problem-solving capacity of the Brazilian Unified Health System (SUS) ${ }^{(1-2)}$.

In this context, the work process of PHC services has growing demand and scope of practices that incorporate new responsibilities every day, causing workers to experience overload and exhaustion. This situation may lead to job dissatisfaction, frustration, and apathy, resulting in a conflicting situation among those workers who believed they would develop and feel satisfied and fulfilled with their jobs ${ }^{(3-5)}$.

This context affects how these workers relate to their careers. For this reason, it is vital to understand how PHC workers are connected with health services. Career commitment and career entrenchment emerge among motivated workers and include divergent behaviors that can cause significant social, organizational, personal, and sanitary impacts ${ }^{(6-7)}$.

Career commitment consists of a positive relationship established between workers and their professions and may give meaning and continuity at work. Committed workers become involved with their organization, jobs, careers and desire to remain and grow in their careers and overcome obstacles ${ }^{(7-8)}$.

On the other hand, career entrenchment means a worker is stagnated in a job position for not having alternatives, fear of losing previous investments, and attempts to avoid potential emotional costs from changing careers. Hence, workers tend to remain in a career, even if dissatisfied, due to previous investments, emotional loss accruing from changing careers, and having no career prospects $^{(7-9)}$.

Career commitment and career entrenchment explain the intention and persistence of workers in the course of action that delimits their occupation and investments to construct a successful personal trajectory that also benefits society. Possibly, career entrenchment does not depend on one's level of commitment; that is, entrenchment and commitment would be different and independent, but not opposing relations, though with different impacts on one's performance ${ }^{(6,10-11)}$.

The Brazilian literature addressing career commitment and career entrenchment is incipient, especially among PHC workers. One study addressing nurses working in hospital settings reports that most are committed to their careers. Such a commitment, explaining why these workers remain in the nursing profession, may be associated with the fact they identify themselves with the profession ${ }^{(7)}$.

International studies addressing health workers report high levels of career commitment, showing that age, the field of work, and years of experience interfere in commitment levels ${ }^{(12-13)}$.

\section{OBJECTIVE}

To assess levels of career commitment and career entrenchment among PHC workers.

\section{METHOD}

\section{Ethical aspects}

Data collection was initiated after the Institutional Review Board at the Medical School of São José do Rio Preto approved the study.

\section{Study design, period, and settings}

This cross-sectional, descriptive, and analytical study was conducted in 2018 in two cities in the state of São Paulo, Brazil, addressing a non-probabilistic, convenience sample composed of PHC workers.

The first city (city A) is located in the north of the state of São Paulo, $452 \mathrm{~km}$ from the capital. According to the Brazilian Institute of Geography and Statistics (IBGE), it is a large city with an estimated population of 438,354 inhabitants. This city hosts the $15^{\text {th }}$ Regional Health Division, the largest in the state of São Paulo, and is a reference in healthcare.

At the time of data collection, the city was divided into five Health Districts. PHC was responsible for 27 municipal services: 10 Basic Health Units (UBS) and 17 Family Basic Health Units (UBSF), with 40 Family Health Strategy (ESF) teams, covering $24 \%$ of the population.

The second city (city B) is located in the state's western region, $596 \mathrm{~km}$ from the capital. It is a small city, with 33,707 inhabitants. The city is a reference in the health field for nine cities in the Nova Alta Paulista region. According to the local healthcare structure, PHC was provided by four Basic Health Units (UBS), with ten ESF covering $100 \%$ of the population.

\section{Population and sample: inclusion and exclusion criteria}

The study's population was 549 workers composing the cities' ESF teams (i.e., nurses, physicians, nursing technicians and aids, and Community Health Agents - CHA): 410 in city A and 139 in city $B$. Those working in ESF teams for at least six months were included in the study. Workers on vacation or any kind of leave during the period of data collection were excluded from the study. The convenience sample was composed of 393 ESF workers.

\section{Study protocol}

Three instruments were used to collect data: a form addressing sociodemographic and occupational variables such as sex, age, education, marital status, family income, type of job contract, whether the worker was the head of the unit, years of experience in PHC; the Brazilian version of the Career Commitment Measure (CCM) by Carson and Bedeian ${ }^{(8,14)}$; and the Brazilian version of the Career Entrenchment Measure (CEM), developed by Carson, Carson and Bedeian ${ }^{(9,15)}$.

CCM is composed of 12 items, distributed into three factors: identity, resilience, and planning. The items are statements that describe attitudes and behaviors toward one's career ${ }^{(8,14)}$. CEM is also composed of 12 items, distributed into three factors: career investments, emotional costs, and limitedness of career alternatives. The CEM items describe perceptions and feelings 
toward the possibility of changing careers ${ }^{(9,15)}$. These measures were validated in Brazil and internationally by researchers from the psychology, administration, and related fields.

Agreement in both measures is rated on a 5-point Likert scale ranging from 1 =strongly disagree; $2=$ disagree; $3=$ neither agree, nor disagree; $4=$ =agree; and 5=strongly agree.

Data collection was scheduled with the health units' managers and conducted during the teams' meetings. After the authors provided clarification regarding the study's objectives, the workers who consented to participate signed free and informed consent forms. After the participants completed the questionnaires, they returned them in unidentified envelopes to ensure the participants' identities would remain confidential. Some participants opted to fill out the questionnaires later, so a date was scheduled to return the completed instruments (approximately one week later).

\section{Data analysis and statistics}

Data were analyzed with SPSS, version 23.0. Descriptive (central tendency and dispersion measures) and exploratory analyses were performed to verify data accuracy, distribution of missing cases, sample size, and sample description. Cronbach's alpha was used to verify the reliability of the measures of the theoretical constructs used in the questionnaire. The following values were found: career commitment $\mathrm{a}=0.795$ and career entrenchment $a=0.792$, both considered good reliability indicators ${ }^{(16)}$.

The sociodemographic and occupational data were used to characterize the study's population. The mean score and standard deviation of the constructs were calculated on a scale from zero to 20 for each factor (identity, planning, and resilience; investments, limited alternatives, and emotional costs) and from zero to 60 for commitment and entrenchment, to verify the workers' relations with their careers. The means of each factor/construct were standardized on a scale from zero to 100 and classified into three categories, according to the mean score: low (zero to 33.3), moderate (33.4 to 66.7), and high (66.8 to 100.0).

The levels of career commitment and career entrenchment established between the workers and their careers were compared between the two cities using the t-test. Finally, the difference between these was verified according to sociodemographic and occupational variables, using the two-sample t-test or analysis of variance (ANOVA) for three or more means, with the significance level established at 95\% ( $p \leq 0.05)$.

\section{RESULTS}

Table 1 shows the distribution of the workers' sociodemographic and occupational profiles per city. Of the universe of workers listed for this study, 393 (71.6\%) were selected, 313 (76.3\%) were from city $A$ and 80 (57.6\%) from city B. The largest contingent of workers was Community Health Agents, representing $45.0 \%$ of the study's total participants. Most workers were women (80.9\%), aged between 31 and 45 years old (46.6\%), with high school (49.1\%), hired through a public competition process $(76.6 \%)$, worked in health care (87.3\%), had an income between two and five times the minimum wage (61.6\%), and worked in the PHC service between one and two years (36.4\%).
Table 2 shows the analysis of career commitment and career entrenchment. No significant statistical differences were found between the workers in the two cities. High scores were obtained in most factors for both constructs (career commitment and career entrenchment), except for the Planning factor, in which the workers from city A obtained a moderate score (65.0) and the workers from city B obtained high scores (68.2). The workers in both cities obtained moderate scores in the Investments factor (63.0 and 61.7 for cities $A$ and $B$, respectively).

The levels of Career commitment [C195\%: 75.5-77.5] presented by the PHC workers were higher $(p<0.001)$ than Career entrenchment levels [C195\%: 66.7-69.2]. Likewise, the levels of Career identity [C195\%: 82.7-85.5] were significantly higher $(p<0.001)$ than levels of Career investments [C195\%: 60.4-65.0], while Career resilience levels [C195\%: 75.1-79.2] were statistically higher $(p<0.001)$ than Career emotional costs [CI95\%:69.0-72.1]. However, the scores [C195\%: 64.2-67.1] obtained in Career planning were significantly lower $(p<0.001)$ than the scores obtained in Limitedness of career alternatives [CI95\%: 68.1-71.0].

Table 1 - Sociodemographic and occupational characteristics of Primary Health Care workers according to city

\begin{tabular}{|c|c|c|}
\hline Variables & $\begin{array}{l}\text { City A } \\
\text { n (\%) }\end{array}$ & $\begin{array}{l}\text { City B } \\
\text { n (\%) }\end{array}$ \\
\hline Total & $313(100.0)$ & $80(100.0)$ \\
\hline $\begin{array}{l}\text { Occupation } \\
\text { Physician } \\
\text { Nurse } \\
\text { Nursing aid/technician } \\
\text { Community health agent }\end{array}$ & $\begin{array}{c}32(10.2) \\
77(24.6) \\
71(22.7) \\
133(42.5)\end{array}$ & $\begin{array}{c}9(11.3) \\
15(18.8) \\
12(15.0) \\
44(55.0)\end{array}$ \\
\hline $\begin{array}{l}\text { Sex } \\
\text { Male } \\
\text { Female } \\
\text { No answer }\end{array}$ & $\begin{array}{c}50(16.0) \\
260(83.1) \\
3(1.0)\end{array}$ & $\begin{array}{c}21(26.3) \\
58(72.5) \\
1(1.3)\end{array}$ \\
\hline $\begin{array}{l}\text { Age } \\
\qquad \begin{array}{l}21 \text { to } 30 \text { years old } \\
31 \text { to } 45 \text { years old } \\
46 \text { to } 60 \text { years old } \\
61 \text { years old or older } \\
\text { No answer }\end{array}\end{array}$ & $\begin{array}{c}47(15.0) \\
145(46.3) \\
100(31.9) \\
9(2.9) \\
12(3.8)\end{array}$ & $\begin{array}{c}11(13.8) \\
38(47.5) \\
25(31.3) \\
- \\
6(7.5)\end{array}$ \\
\hline $\begin{array}{l}\text { Education } \\
\text { High School } \\
\text { Bachelor's degree } \\
\text { Graduate studies } \\
\text { No answer }\end{array}$ & $\begin{array}{l}149(47.6) \\
67(21.4) \\
97(31.0) \\
-\end{array}$ & $\begin{array}{l}44(55.1) \\
17(21.3) \\
18(22.5) \\
1(1.3)\end{array}$ \\
\hline $\begin{array}{l}\text { Type of contract } \\
\text { Public competition } \\
\text { Hired } \\
\text { No answer }\end{array}$ & $\begin{array}{c}235(75.1) \\
73(23.3) \\
5(1.6)\end{array}$ & $\begin{array}{c}66(82.5) \\
14(17.5) \\
-\end{array}$ \\
\hline $\begin{array}{l}\text { Position } \\
\text { Administrative } \\
\text { Care delivery } \\
\text { No answer }\end{array}$ & $\begin{array}{c}36(11.5) \\
274(87.5) \\
3(1.0)\end{array}$ & $\begin{array}{c}10(12.5) \\
69(87.6) \\
-\end{array}$ \\
\hline $\begin{array}{l}\text { Family Income (Minimum wage) } \\
\text { Up to } 1 \text { times the M.W. } \\
\text { From } 2 \text { to } 5 \text { times the M.W. } \\
\text { From } 6 \text { to } 10 \text { times the M.W. } \\
\text { More than } 10 \text { times the M.W. } \\
\text { No answer }\end{array}$ & $\begin{array}{c}23(7.3) \\
185(59.1) \\
61(19.5) \\
38(12.1) \\
6(1.9)\end{array}$ & $\begin{array}{c}12(15.0) \\
57(71.3) \\
6(7.5) \\
5(6.3) \\
\quad-\end{array}$ \\
\hline $\begin{array}{l}\text { Experience in PHC (years) } \\
\quad<1 \text { to } 2 \\
\quad>2 \text { to } 10 \\
>10 \text { to } 20 \\
\quad>20 \\
\text { No answer }\end{array}$ & $\begin{array}{l}122(39.0) \\
49(15.7) \\
65(20.8) \\
62(19.8) \\
15(4.8)\end{array}$ & $\begin{array}{l}21(26.3) \\
30(37.5) \\
12(15.0) \\
15(18.8) \\
2(2.5)\end{array}$ \\
\hline
\end{tabular}


Table 2 - Mean scores and standard deviations for the constructs and dimensions of the relations established between Primary Health Care workers and their careers

\begin{tabular}{|c|c|c|c|}
\hline Career bonds & $\begin{array}{c}\text { City A } \\
\text { Mean }( \pm s d)\end{array}$ & $\begin{array}{c}\text { City B } \\
\text { Mean }( \pm s d)\end{array}$ & $p$ value \\
\hline Career commitment & $76.5(9.7)$ & $76.8(11.2)$ & 0.805 \\
\hline Career identity & $84.3(14.2)$ & $83.4(14.5)$ & 0.606 \\
\hline Career planning & $65.0(13.7)$ & $68.2(18.3)$ & 0.078 \\
\hline Career resilience & $77.6(20.4)$ & $75.6(20.5)$ & 0.456 \\
\hline Career entrenchment & $67.7(12.1)$ & $68.7(13.9)$ & 0.530 \\
\hline Career investments & $63.0(22.5)$ & $61.7(24.3)$ & 0.654 \\
\hline Limitedness of career alternatives & $69.2(14.5)$ & $71.1(13.4)$ & 0.289 \\
\hline Career emotional costs & $70.1(15.3)$ & $72.4(17.8)$ & 0.238 \\
\hline
\end{tabular}

Younger workers presented the lowest level of Career identity (78.8) and the highest level of Career resilience (80.8). Those with a graduate degree experienced the highest level of Career identity (88.4), Career investments (74.0) and Limitedness of career alternatives (73.6), and the lowest level of Career planning (63.0).

The workers hired through public competition presented the lowest level of Career identity (82.4), with higher levels of Career planning (66.8) and Career resilience $(79.3)$ than hired workers $(p<0.05)$. Those holding a manager position in the UBS presented higher levels of Career identity (87.4), Career invest-

According to sociodemographic and occupational characteristics, the analysis concerning the relations established by the PHC workers with their careers (Table 3 ) shows that the physicians had a higher level of Career identity (92.4) and Career investments (79.5) than the remaining workers. At the same time, $\mathrm{CHA}$ presented the lowest levels of Career identity (79.0) and Career investments (52.3), and the nurses were the professionals who presented the highest level of Limitedness of career alternatives (73.4). ments (73.0), and Limitedness of career alternatives (72.5) than those working with care delivery.

Additionally, the higher the income, the higher the levels of Career identity $(p=0.040)$ and Career investments $(p=0.002)$ and the lower the level of Career planning $(p=0.039)$. Workers with lower incomes (up to one times the minimum wage) or very high incomes (above six times the minimum wage) presented the highest levels of Limitedness of career alternatives $(p=0.000)$.

Table 3 - Distribution of mean scores and standard deviations for the constructs and dimensions of the career relationships, according to the Primary Health Care workers' sociodemographic and occupational characteristics

\begin{tabular}{|c|c|c|c|c|c|c|c|c|}
\hline \multirow{2}{*}{$\begin{array}{l}\text { Sociodemographic and } \\
\text { occupational variables }\end{array}$} & \multicolumn{4}{|c|}{ Career Commitment } & \multicolumn{4}{|c|}{ Career Entrenchment } \\
\hline & Identity & Planning & Resilience & $\begin{array}{l}\text { General } \\
\text { construct }\end{array}$ & Investments & $\begin{array}{l}\text { Limited } \\
\text { alternatives }\end{array}$ & $\begin{array}{l}\text { Emotional } \\
\text { costs }\end{array}$ & $\begin{array}{l}\text { General } \\
\text { construct }\end{array}$ \\
\hline \multicolumn{9}{|l|}{ Profession } \\
\hline Physician & $92.4(10.7)^{b}$ & $61.7(10.4)^{a}$ & $72.4(22.9)^{b}$ & $76.6(9.4)^{b}$ & $75.9(25.5)^{b}$ & $71.3(15.2)^{b}$ & $67.1(17.2)^{b}$ & $72.6(15.7)^{b}$ \\
\hline Nurse & $87.2(10.1)^{b}$ & $63.5(13.1)^{a}$ & $77.1(20.6)^{b}$ & $76.7(8.5)^{b}$ & $71.4(21.5)^{b}$ & $73.4(10.5)^{b}$ & $71.2(12.7)^{b}$ & $72.3(9.4)^{b}$ \\
\hline Nursing technician/Aid & $87.4(11.7)^{b}$ & $68.0(15.3)^{b}$ & $75.6(20.8)^{b}$ & $77.8(10.5)^{b}$ & $68.9(21.6)^{b}$ & $71.2(16.3)^{b}$ & $68.9(14.8)^{b}$ & $69.9(12.2)^{b}$ \\
\hline Community health agent & $79.0(16.0)^{b}$ & $66.6(16.0)^{\mathrm{a}}$ & $79.0(19.4)^{b}$ & $75.8(10.7)^{b}$ & $52.3(18.7)^{\mathrm{a}}$ & $66.4(14.2)^{a}$ & $71.8(17.4)^{b}$ & $63.7(11.8)^{a}$ \\
\hline$p$ value & 0.000 & 0.054 & 0.250 & 0.533 & 0.000 & 0.001 & 0.247 & 0.000 \\
\hline \multicolumn{9}{|l|}{ Age } \\
\hline 21 to 30 years old & $78.8(17.8)^{b}$ & $66.0(15.8)^{\mathrm{a}}$ & $80.8(18.4)^{b}$ & $76.3(9.0)^{b}$ & $56.5(24.5)^{\mathrm{a}}$ & $66.3(14.9)^{a}$ & $71.8(15.2)^{b}$ & $65.1(13.0)^{a}$ \\
\hline 31 to 45 years old & $84.6(13.6)^{b}$ & $64.7(15.0)^{a}$ & $78.6(19.8)^{b}$ & $77.0(9.8)^{b}$ & $63.9(22.2)^{\mathrm{a}}$ & $71.0(12.6)^{b}$ & $70.7(15.1)^{b}$ & $68.9(11.7)^{b}$ \\
\hline 46 to 60 years old & $85.1(13.2)^{b}$ & $66.8(13.8)$ & $74.3(20.7)^{b}$ & $75.9(10.4)^{b}$ & $63.6(22.7)^{\mathrm{a}}$ & $68.6(15.6)^{b}$ & $69.6(16.4)^{b}$ & $67.6(13.1)^{b}$ \\
\hline 61 years old or older & $91.0(14.4)^{b}$ & $59.0(11.7)^{a}$ & $58.3(28.8)^{a}$ & $70.8(11.6)^{b}$ & $62.5(25.2)^{\mathrm{a}}$ & $72.9(21.4)^{b}$ & $75.7(24.7)^{b}$ & $72.0(16.9)^{b}$ \\
\hline$p$ value & 0.012 & 0.352 & 0.005 & 0.296 & 0.167 & 0.116 & 0.628 & 0.162 \\
\hline \multicolumn{9}{|l|}{ Education } \\
\hline High School & $82.6(13.7)^{b}$ & $67.5(15.3)$ & $78.4(20.0)^{b}$ & $77.0(10.8)^{b}$ & $58.5(20.6)^{a}$ & $68.6(15.1)^{b}$ & $69.5(17.0)^{b}$ & $65.8(12.3)^{a}$ \\
\hline College & $82.1(17.6)^{b}$ & $65.5(14.9)^{a}$ & $76.1(19.6)^{b}$ & $75.5(9.1)^{\mathrm{b}}$ & $57.2(23.1)^{\mathrm{a}}$ & $66.5(13.7)^{a}$ & $71.9(15.1)^{b}$ & $65.4(12.1)^{a}$ \\
\hline Graduate studies & $88.4(10.9)^{b}$ & $63.0(13.2)^{a}$ & $76.0(21.7)^{b}$ & $76.7(9.0)^{b}$ & $74.0(22.4)^{b}$ & $73.6(12.2)^{b}$ & $71.4(14.4)^{b}$ & $73.6(11.2)^{b}$ \\
\hline$p$ value & 0.001 & 0.035 & 0.547 & 0.526 & 0.000 & 0.001 & 0.425 & 0.000 \\
\hline \multicolumn{9}{|l|}{ Job contract } \\
\hline Public competition & $82.4(14.8)^{b}$ & $66.8(15.0)$ & $79.3(19.7)^{b}$ & $77.1(10.2)^{b}$ & $61.5(21.9)^{\mathrm{a}}$ & $69.0(14.2)^{b}$ & $71.0(16.1)^{b}$ & $67.4(12.3)^{b}$ \\
\hline Hired & $89.9(10.4)^{b}$ & $62.0(13.2)^{\mathrm{a}}$ & $71.3(21.2)^{b}$ & $75.3(9.2)^{b}$ & $67.5(25.0)^{b}$ & $72.2(13.7)^{b}$ & $69.2(14.9)^{b}$ & $70.1(12.8)^{b}$ \\
\hline$p$ value & 0.000 & 0.005 & 0.001 & 0.127 & 0.029 & 0.056 & 0.332 & 0.083 \\
\hline \multicolumn{9}{|l|}{ Field of work } \\
\hline Managerial & $87.4(10.2)^{b}$ & $65.4(14.2)^{\mathrm{a}}$ & $78.3(19.0)^{b}$ & $78.1(7.5)^{b}$ & $73.0(18.8)^{b}$ & $72.5(6.9)^{b}$ & $68.3(12.0)^{b}$ & $71.5(7.7)^{b}$ \\
\hline Healthcare delivery & $83.6(14.7)^{b}$ & $65.7(14.9)^{\mathrm{a}}$ & $77.1(20.5)^{b}$ & $76.3(10.3)^{b}$ & $61.4(23.1)^{\mathrm{a}}$ & $69.2(15.0)^{b}$ & $70.9(16.3)^{b}$ & $67.5(12.9)^{b}$ \\
\hline$p$ value & 0.031 & 0.890 & 0.695 & 0.172 & 0.000 & 0.014 & 0.194 & 0.004 \\
\hline \multicolumn{9}{|c|}{ Family Income (Minimum wage) } \\
\hline Up to $1 \mathrm{MW}$ & $82.4(14.1)^{b}$ & $70.1(16.6)$ & $79.3(18.7)^{b}$ & $78.0(9.8)^{b}$ & $57.6(17.2)^{\mathrm{a}}$ & $70.1(12.9)^{b}$ & $74.1(17.9)^{b}$ & $67.5(10.2)^{b}$ \\
\hline From 2 to $5 \mathrm{MW}$ & $82.9(14.9)^{b}$ & $66.0(15.3)^{\mathrm{a}}$ & $78.0(20.0)^{b}$ & $76.6(10.6)^{b}$ & $59.3(22.4)^{\mathrm{a}}$ & $68.4(15.0)^{b}$ & $70.7(16.1)^{b}$ & $66.3(12.5)^{a}$ \\
\hline From 6 to $10 \mathrm{MW}$ & $85.7(12.1)^{b}$ & $65.2(12.5)^{\mathrm{a}}$ & $75.1(21.4)^{b}$ & $75.9(8.9)^{b}$ & $71.2(22.5)^{b}$ & $73.8(12.5)^{b}$ & $68.6(12.7)^{b}$ & $71.8(11.6)^{b}$ \\
\hline More than $10 \mathrm{MW}$ & $89.1(12.9)^{b}$ & $60.6(12.6)^{a}$ & $76.2(21.7)^{b}$ & $76.4(9.1)^{b}$ & $74.9(23.1)^{b}$ & $70.1(12.9)^{b}$ & $69.0(17.0)^{b}$ & $72.1(13.1)^{b}$ \\
\hline$p$ value & 0.040 & 0.039 & 0.682 & 0.794 & 0.002 & 0.000 & 0.056 & 0.361 \\
\hline \multicolumn{9}{|l|}{ Experience in $\mathrm{PHC}$ (years) } \\
\hline$<1$ to 2 & $80.6(16.9)^{b}$ & $64.4(14.5)^{a}$ & $77.6(20.0)^{b}$ & $75.3(10.6)^{b}$ & $53.8(22.7)^{\mathrm{a}}$ & $65.8(14.2)^{a}$ & $73.2(16.3)^{b}$ & $64.5(12.3)^{a}$ \\
\hline$>2$ to 10 & $87.1(13.0)^{b}$ & $67.0(15.3)$ & $75.8(20.1)^{b}$ & $77.7(9.7)^{b}$ & $67.3(21.7)^{b}$ & $73.4(12.5)^{b}$ & $72.1(15.8)^{b}$ & $71.4(12.1)^{b}$ \\
\hline$>10$ to 20 & $83.8(12.0)^{b}$ & $66.2(15.2)^{\mathrm{a}}$ & $79.1(20.9)^{b}$ & $77.0(10.2)^{b}$ & $63.6(20.4)^{a}$ & $71.0(15.2)^{b}$ & $69.3(15.2)^{b}$ & $68.0(11.8)^{b}$ \\
\hline$>20$ & $87.5(11.4)^{b}$ & $65.9(15.4)^{a}$ & $75.7(21.7)^{b}$ & $77.1(9.5)^{b}$ & $73.8(22.0)^{b}$ & $71.0(13.9)^{b}$ & $66.9(15.0)^{b}$ & $71.2(12.7)^{b}$ \\
\hline$p$ value & 0.001 & 0.638 & 0.691 & 0.342 & 0.000 & 0.000 & 0.001 & 0.031 \\
\hline
\end{tabular}

PHC - Primary Health Care; M.W.- Minimum wage; ${ }^{a}$ Moderate level ${ }^{b}$ High level 
Regarding years of experience in $\mathrm{PHC}$, those working for up to two years presented the lowest levels of Career identity (80.6), Career investments (53.8), and Limitedness of career alternatives $(65,8)$, and higher Emotional costs (73.2).

Levels of Career commitment and Career entrenchment between sexes were equivalent, with no significant differences between men and women ( $p>0.05)$.

\section{DISCUSSION}

The workers addressed in this study compose the minimum ESF team as recommended by the Política Nacional de Atenção Básica (PNAB) ${ }^{(17)}$ [Primary Health Care National Policy], and their profiles corroborate those profiles reported by studies conducted in different Brazilian regions ${ }^{(3-5,18-22)}$.

Most workers were women, ratifying the feminization phenomenon, which has occurred since the 1990s in most professions in the healthcare field, except for the Nursing field, in which masculinization has occurred ${ }^{(23)}$.

High levels of Career commitment show that despite difficulties, the workers have a positive relationship with their professions and find meaning in their practice within PHC services. These results are in line with international studies addressing nonmedical workers from the Council of Academic Family Medicine in the United States and Canada ${ }^{(12)}$, and Egyptian ${ }^{(13)}$, and Saudis nurses ${ }^{(24)}$. However, these levels are higher than those presented by Brazilian nurses working in hospital facilities ${ }^{(7)}$. The social support provided to workers positively impacts their level of Career commitment $^{(13,24)}$.

However, given territorial and occupational differences as well as differences in lifestyle in the various Brazilian regions, and more flexible labor terms, these positive results do not represent the context of all PHC workers in Brazil ${ }^{(25)}$. Workers with precarious job contracts are likely to present different results.

Despite the attempts of the Programa Nacional de Desprecarização do Trabalho [National Program for Safer Labor Contracts] to strengthen job contracts within SUS to implement humanization policies, effective job contracts, and higher salaries, the Terceiro Ciclo da Avaliação Externa do Programa de Melhoria do Acesso e da Qualidade da Atenção Básica (PMAQ-AB) [Third Cycle of the External Evaluation of the Program for Improvement of Access and Quality of Primary Health Care] shows that approximately $40 \%$ of the PHC workers are hired under precarious contracts, with temporary or informal jobs ${ }^{(26-27)}$. On the one hand, the PHC workers' job stability is associated with a career plan that values professional growth and development, increasing one's level of career commitment. On the other hand, more flexible Brazilian labor laws and consequent precarious job contracts undermine job stability, social rights and worsen the conditions of job contracts, leading to increased levels of career entrenchment ${ }^{(7,12,28)}$.

Additionally, the moderate levels of career planning reveal workers have limited ability to establish goals for career development(7-8), especially among those workers with lower educational levels, such as Nursing technicians and aids and $\mathrm{CHA}$, who in general face more significant financial restrictions. Workers with a college degree, i.e., higher education and higher incomes, have higher levels of investment and emotional loss in case of a career change, leading to higher levels of career entrenchment (stagnation).

Being stagnated in a job position in the current context of labor relations because of a lack of options and unwillingness to lose investments and avoid emotional costs related to career changes may lead to insecurity, low self-esteem, social or affective ruptures, and a feeling of failure. For this reason, workers may limit their roles to merely meet the population's needs and implement actions that effectively meet the community's needs, however compromising the quality and problem-solving capacity of PHC services ${ }^{(28-29)}$.

Considering the sociology of professions, which categorizes the phases of professional life and time since graduation to entering the job market, most of the workers addressed in this study are in the phase of professional maturity. In this phase, workers are prepared to consolidate themselves in the job market because they have the qualification and technical, cognitive, and practical skills fully developed ${ }^{(23,30)}$. This professional maturity is reinforced by significantly higher levels of career identity among older workers and those with long experience in $\mathrm{PHC}$.

In this context, high levels of career identity confirm that the workers addressed here are emotionally attached to their careers, desire to grow and achieve professional recognition, and the work they perform positively influences their self-esteem. It is a favorable situation because when workers invest in their abilities and knowledge, they focus on their careers, contributing to improved performance ${ }^{(6-8)}$.

High levels of career resilience show that workers can overcome diverse situations faced within PHC, generally associated with organizational and managerial issues such as precarious work conditions, lack of autonomy and professional recognition, a deficit in the number of workers, and work overload ${ }^{(29,31)}$. Workers with high levels of career resilience can work with the team, and being simultaneously independent and cooperative, essential aspects for meeting the PNAB's guidelines ${ }^{(17)}$.

At the same time, younger workers present higher career resilience, struggle to enter and remain in the job market, have two or three jobs, and simultaneously work in the day and night shifts, leading to exhaustion and distress ${ }^{(32-33)}$; hence, the need and importance of career resilience among workers.

According to the literature, resilience may represent a new focus on the positivity in the workers' actions when facing challenges and adversities in their daily routine, with the possibility of learning and transformation that may reflect in their practice ${ }^{(29)}$. Therefore, workers' relationships with their careers are a matter of public health, as these relationships may jeopardize the strengthening of EFS and PHC as the SUS' organizing components. In this sense, job demands that are not equivalent to the PHC workers' abilities, expectations, or needs, thus, encourage entrenchment and undermine commitment, are a modern challenge imposed on workers' health.

\section{Study limitations}

This study's limitations include the difficulty in comparing the results with other studies addressing this topic due to a lack of investigations conducted in health facilities, especially among 
Career commitment and career entrenchment among Primary Health Care workers Lourenção LG, Oliveira JF, Ximenes Neto FR, Cunha CLF, Valenzuela-Suazo SV, Borges MA, et al.

PHC workers, the fact the study was restricted to two cities in the state of São Paulo, preventing comparisons and discussions concerning different Brazilian regions. Hence, future studies are recommended to address workers from other Brazilian regions to compare career commitment and entrenchment among PHC workers from different contexts and work situations, contributing to deepening discussions about this theme.

\section{Contributions for the nursing field and public health}

This study contributes to (re)direct the implementation of public policies that promote the personal and professional development of PHC workers, to consolidate the Política $\mathrm{Na}$ cional de Atenção Básica [Primary Health Care National Policy], improve the problem-solving capacity of $\mathrm{PHC}$ services, and strengthen SUS.

\section{CONCLUSIONS}

The relationship presented by most PHC workers was career commitment, showing that the workers more frequently identify and have a positive relationship with their careers, instead of stagnation. This relationship indicates that the workers remain in their careers because they identify themselves with their occupation/profession, are resilient, and are less frequently aware of their potential and limitations.

Regarding career entrenchment, the results show that physicians first consider career investments, lack of professional prospects outside their field of practice, and emotional loss before quitting their professions. Nurses and nursing technicians/aids consider a lack of professional prospects outside their field, careers investments, and emotional costs. Finally, CHA assess emotional costs, lack of professional prospects outside their field, and career investments.

\section{REFERENCES}

1. Damascena DM, Vale PRLF. Typologies of precarious work in primary healthcare: a netnographic study. Trab Educ Saúde. 2020;18(3):e00273104. https://doi.org/10.1590/1981-7746-sol00273 Portuguese.

2. Nogueira ML. Expressions of precariousness in the work of community health agents: bureaucratization and estrangement of the work. Saude Soc. 2019;28(3):309-23. https://doi.org/10.1590/s0104-12902019180783

3. Cordioli DFC, Cordioli Jr JR, Gazetta CE, Silva AG, Lourenção LG. Occupational stress and engagement in primary health care workers. Rev Bras Enferm. 2019;72(6):1580-7. https://doi.org/10.1590/0034-7167-2018-0681

4. Lourenção LG, Silva AG, Borges MA. Levels of engagement in primary health care professionals: a comparative study in two Brazilian municipalities. Esc Anna Nery. 2019;23(3):e20190005. https://doi.org/10.1590/2177-9465-ean-2019-0005

5. Cordioli Jr JR, Cordioli DFC, Gazetta C, Silva AG, Lourenção LG. Quality of life and osteomuscular symptoms in workers of primary health care. Rev Bras Enferm. 2020;73(5):e20190054. https://doi.org/10.1590/0034-7167-2019-0054

6. Falcão AC, Bastos AVB, Rodrigues ACA. Comprometimento e entrincheiramento na carreira: integrar ou reconstruir os construtos? Uma exploração das relações à luz do desempenho. Rev Adm (São Paulo). 2013;48(3):530-43. https://doi.org/10.5700/rausp1104

7. Lima MP, Costa VMF, Lopes LFD, Balsan LAG, Santos AS, Tomazzoni GC. Levels of career commitment and career entrenchment of nurses from public and private hospitals. Rev Latino-Am Enfermagem. 2015;23(6):1033-40. https://doi.org/10.1590/0104-1169.0211.2646

8. Magalhães MO. Propriedades psicométricas da versão brasileira da escala de comprometimento com a carreira. Psicol Cienc Prof. 2013;33(2):303-17. https://doi.org/10.1590/S1414-98932013000200005

9. Magalhães MO. Propriedades psicométricas da versão brasileira da Escala de Entrincheiramento na Carreira. PsicoUSF [Internet]. 2008 [cited 2020 Apr 14];13(1):13-9. Available from: http://pepsic.bvsalud.org/scielo.php?script=sci_arttext\&pid=S1413-82712008000100003\&lng=pt\&nrm=iso

10. Rodrigues ACA, Bastos AVB, Moscon DCB. Delimiting the concept of organizational commitment: empirical evidence of the overlap between the entrenchment and the continuance mindset. Organ Soc. 2019;26(89):338-58. https://doi.org/10.1590/1984-9260897

11. Zacher H, Ambiel RAM, Noronha APP. Career adaptability and career entrenchment. J Vocat Behav. 2015;88:164-73. https://doi. org/10.1016/j.jvb.2015.03.006

12. Mainous AG, Rahmanian KP, Ledford CJ, Carek PJ. Professional identity, job satisfaction, and commitment of nonphysician faculty in academic family medicine. Fam Med. 2018;50(10):739-45. https://doi.org/10.22454/FamMed.2018.273724

13. Elewa $A H$, Abed F. Nursing profession as perceived by staff nurses and its relation to their career commitment at different hospitals. IJND. 2017;7(1):13-22. https://doi.org/10.15520/ijnd.2017.vol7.iss01.188.13-22

14. Carson KD, Bedeian AG. Career commitment: construction of a measure and examination of its psychometric properties. J Vocat Behav. 1994;44(3):237-62. https://doi.org/10.1006/jvbe.1994.1017

15. Carson KD, Carson PP, Bedeian AG. Development and construct validation of a career entrenchment measure. J Occup Organ Psychol. 1995;68(4):301-20. https://doi.org/10.1111/j.2044-8325.1995.tb00589.x

16. Souza AC, Alexandre NMC, Guirardello EB. Psychometric properties in instruments evaluation of reliability and validity. Epidemiol Serv Saúde. 2017;26(3):649-59. https://doi.org/10.5123/s1679-49742017000300022

17. Ministério da Saúde (BR). Portaria n².436, de 21 de setembro de 2017. Aprova a Política Nacional de Atenção Básica, estabelecendo a revisão de diretrizes para a organização da Atenção Básica, no âmbito do Sistema Único de Saúde (SUS) [Internet]. Brasília, DF: Ministério da 
Saúde, 2017 [cited 2020 Jun 12]. Available from: http://pesquisa.in.gov.br/imprensa/jsp/visualiza/index.jsp?data=22/09/2017\&jornal=1\&pa gina $=68 \&$ total Arquivos $=120$

18. Freire Filho JR, Costa MV, Magnago C, Forster AC. Attitudes towards interprofessional collaboration of Primary Care teams participating in the 'More Doctors' (Mais Médicos) program. Rev Latino-Am Enfermagem. 2018;26:e3018. https://doi.org/10.1590/1518-8345.2731.3018

19. Morosini MV, Fonseca AF. Community workers in Primary Health Care in Brazil: an inventory of achievements and challenges. Saúde Debate. 2018;42(spe1):261-74. https://doi.org/10.1590/0103-11042018s117

20. Santos LS, Souza CE, Monteiro MC, Prado MRMC, Prado Jr PP, Ayres LFA, et al. Perfil social-profissional de enfermeiros e médicos da Atenção Primária à Saúde de uma microrregião geográfica. Enferm Bras. 2019;18(4):552-560. https://doi.org/10.33233/eb.v18i4.2756

21. Sturmer G, Pinto M, Oliveira M, Dahmer A, Stein A, Plentz R. Perfil dos profissionais da Atenção Primária à Saúde, vinculados ao curso de Especialização em Saúde da Família UNA-SUS no Rio Grande do Sul. Rev Conhec Online. 2020;12(1):4-26. https://doi.org/10.25112/rco. v1i0.1639

22. Silva AG, Cabrera EMS, Gazetta CE, Sodré PC, Castro JR, Cordioli Jr JR, et al. Engagement in primary health care nurses: a cross-sectional study in a Brazilian city. Public Health Nurs. 2020;37(2):69-177. https://doi.org/10.1111/phn.12694

23. Machado MH, Filho W, Lacerda W, Oliveira E, Lemos W, Wermelinger M, et al. Características gerais da Enfermagem: o perfil sócio demográfico. Enferm Foco. 2016;7(ed.espe.):9-14. https://doi.org/10.21675/2357-707X.2016.v7.nESP.686

24. Azim MT, Islam MM. Social support, religious endorsement, and career commitment: a study on saudi nurses. Behav Sci (Basel). 2018;8(1):8. https://doi.org/10.3390/bs8010008

25. Godinho MR, Ferreira AP, Fayer VA, Bonfatti RJ, Greco RM. Capacidade para o trabalho e fatores associados em profissionais no Brasil. Rev Bras Med Trab. 2017;15(1):88-100. http://doi.org/10.5327/Z1679443520177012

26. Ministério da Saúde (BR). Secretaria de Atenção Primária à Saúde. Programa de Melhoria da Atenção Básica - 3 Ciclo [Internet]. 2019 [cited 2020 Jun 12]. Available from: https://aps.saude.gov.br/ape/pmaq/ciclo3/

27. Silva PMC, Souza KR, Teixeira LR. Política de desprecarização do trabalho em saúde em uma instituição federal de C\&T: a experiência de professores e pesquisadores. Trab Educ Saúde. 2017;15(1):95-116. https://doi.org/10.1590/1981-7746-sol00048

28. Magalhães ECV, Gomes L. Desemprego e saúde mental: uma análise temática no Brasil [Internet]. Intervozes: trabalho, saúde, cultura. 2018 [cited 2020 Jun 12];3(1):64-87. Available from: http://www.fmpfase.edu.br/Intervozes/Content/pdf/Artigo/Artigo_04_04_03Desempregoes audemental.pdf

29. Costa IP, Moreira DA, Brito MJM. Meanings of work: articulation with mechanisms of risk and protection for resilience. Texto Contexto Enferm. 2020 29:e20190085. https://doi.org/10.1590/1980-265x-tce-2019-0085

30. Machado M, Oliveira E, Lemos W, Lacerda W, Aguiar Filho W, Wermelinger M, et al. Mercado de trabalho da enfermagem: aspectos gerais. Enferm Foco. 2016;7(ed.espe.):35-53. https://doi.org/10.21675/2357-707X.2016.v7.nESP.691

31. Giovanella L, Mendonça MHM, Fausto MCR, Almeida PF, Bousquat A, Lima JG, et al. Emergency supply of doctors by the Mais Médicos (More Doctors) Program and the quality of the structure of primary health care facilities. Ciênc Saúde Colet. 2016;21(09):2697-708. https://doi. org/10.1590/1413-81232015219.16052016

32. Silveira SLM, Câmara SG, Amazarray MR. Preditores da Síndrome de Burnout em profissionais da saúde na atenção básica de Porto Alegre/ RS. Cad Saúde Colet. 2014;22(4):386-92. https://doi.org/10.1590/1414-462X201400040012

33. Maissiat GS, Lautert L, Dal Pai D, Tavares JP. Work context, job satisfaction and suffering in primary health care. Rev Gaúcha Enferm. 2015;36(2):42-9. https://doi.org/10.1590/1983-1447.2015.02.51128 